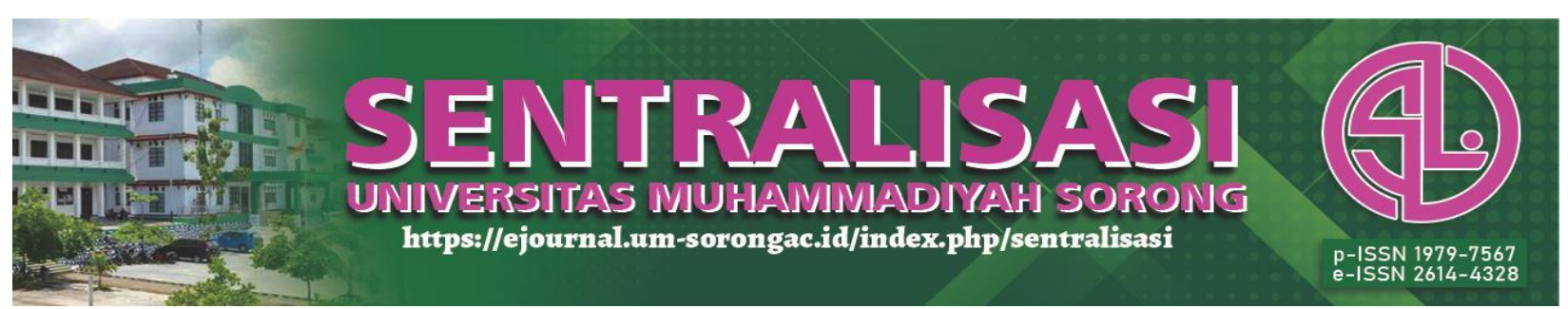

\title{
The Effect of Stand Location and Booth Design on Purchase Decisions Through Positive Emotion
}

\author{
Laily Muzdalifah $^{1 *}$, Ayu Lucy Larassaty ${ }^{2}$, Umniyah Mar'atun Sholichah $^{3}$ \\ ${ }^{1,2,3}$ Fakultas Ekonomi, Universitas Nahdlatul Ulama Sidoarjo, Indonesia \\ E-mail : *lailymuzdalifah.fe.unusida@gmail.com \\ *corresponding author
}

revised: 23/06/2021 published: 30/06/2021

\begin{abstract}
Abstrak. Penelitian ini bertujuan untuk menentukan pengaruh stand location dan design booth terhadap keputusan pembelian melalui positive emotion. Jenis penelitian kuantitatif dengan pendekatan deskriptif. Sampel penenlitian sebesar 100 responden. Tempat penelitian ini yaitu pada acara event wedding tangguh yang diselenggarakan pada Icon Mall Gresik, MOG Malang dan CITO Surabaya. Sampel di ambil dengan metode accidental sampling, sedangkan teknik pengumpulan data menggunakan kuesioner, dokumentasi dan observasi. Teknik analisis data menggunakan Path Analysis. Hasil penelitian menunjukkan 1) Stand location berpengaruh terhadap positive emotion, 2) Design booth berpengaruh terhadap positive emotion, 3) Positive emotion berpengaruh terhadap keputusan pembelian, 4) Stand location berpengaruh terhadap keputusan pembelian, 5) Design booth berpengaruh terhadap keputusan pembelian, 6) Stand location berpengaruh terhadap keputusan pembelian melalui positive emotion, 7) Design booth berpengaruh terhadap keputusan pembeliaan melalui positive emotion.
\end{abstract}

Kata kunci: Stand Location, Design Booth, keputusan pembelian, Positive Emotion.

\begin{abstract}
This study is aimed to determine the effect of stand location and booth design on purchasing decisions through positive emotion. This research is a quantitative research using descriptive approach. The research sample is 100 respondents. The research setting is at wedding events that held in Icon Mall Gresik, MOG Malang and CITO Surabaya. The sample was taken by accidental sampling method, while the data collection technique used a questionnaire, documentation and observation. Data analysis technique using Path Analysis. The results shows that; 1) Stand location had an effect on positive emotion, 2) Booth design had an effect on positive emotion, 3) Positive emotion had an effect on purchasing decisions, 4) Stand location had an effect on purchasing decisions, 5) Booth design had an effect on purchasing decisions, 6) Stand location affects the purchasing decisions through positive emotions, 7) Booth design affects purchasing decisions through positive emotions.
\end{abstract}

Keywords: Stand Location, Booth Design, Purchase Decisions, Positive Emotion

\section{Introduction}

Tangguh East Java Wedding Exhibition is one of the largest wedding exhibitions in East Java organized by Noble Entertainment. It is known that since the Covid-19 pandemic, the wedding business is one of the businesses that has been most affected. Many entrepreneurs in the wedding business have experienced a decline in jobs, decreased profits and decreased events. It is due to several government policies that prohibit activities that cause crowds and calls for the implementation of health protocols. This rule is one of the factors for prospective consumers to be reluctant to hold wedding celebrations.

The emergence of wedding exhibitions has made wedding service entrepreneurs to start 


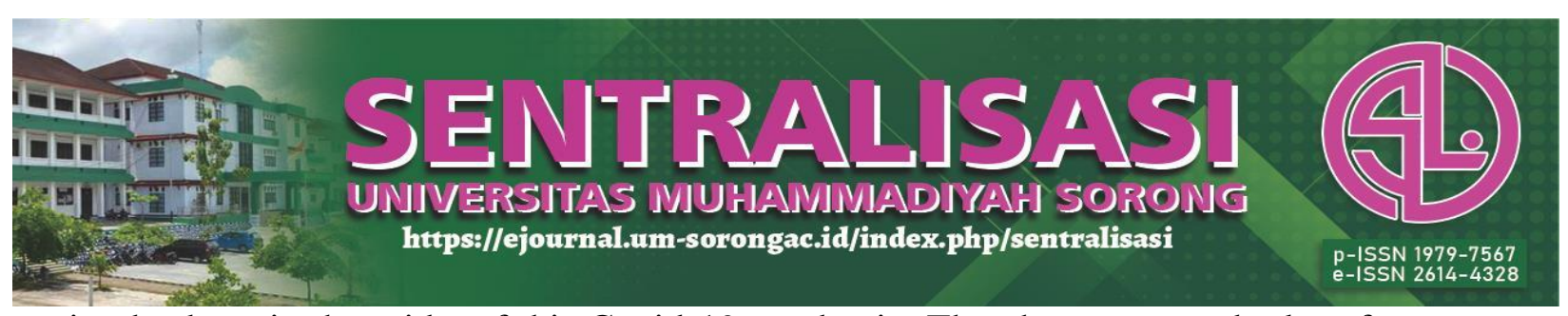

getting back up in the midst of this Covid-19 pandemic. They have to spend a lot of money to take part in a wedding exhibition. The prices for wedding exhibition stands at Icon Mall Gresik, CITO Surabaya and at MOG Malang are between 8 million up to 15 million according to the selected stand location. The wedding exhibitors not only must pay for booth rentals, but also prepare a special booth design to attract the exhibition visitors' attention.

Stand location has an effect on purchasing decisions (Baiti, Purba, and Yandi 2013). Meanwhile, Fatiara, Silitonga, \& Eviana (2017) show that the factors used in choosing a location to hold events are 1) entrance, 2) clarity of circumstances, 3) traffic, 4) environment, 5) competition, 6) government regulations. Bloch et al. (2017) explained that in booth design, an exhibitor collects a number of elements such as overall booth size, design idioms, shapes, finishing materials, music, complexity, lighting, layout, and signage. There are 4 elements that can be used in using the booth design (Bloch et al. 2017): "surface decoration, color temperature, booth layout, and overall shape". The reflection of positive values shown by enthusiastic, happy and detailed customers are called Positive emotion. Positive responses that pay attention to buying behavior can be devided into 3 variables, namely; pleasure, passion, and dominance (Hermanto, 2016).

The strategic stand location is expected to generate positive emotions for visitors which in turn will encourage consumers to make a purchase. In the exhibition organized by wedding business entrepreneurs, they design their booth which of the designs must be real as when presented at a wedding. In the catering business specifically for weddings, when the entrepreneurs attend wedding events, the booth design must represent the catering decoration model that will be served at the wedding celebration. The catering decoration model presented at the exhibition will give consumers an idea of the concept that will be brought when presented by the catering entrepreneur on the wedding day of the bride and groom.

Syiar, Silitonga \& Nova (2017); Mita, Antony and Ferdi (2013) explain that location has an influence on buying decisions, meaning that the better the location is chosen, the more consumers are able to make consumer decisions. Meanwhile, in contrast to the opinion of Fawzeya (2017), he explains that if the location does not affect the buying decision. The existence of this research gap indicates that there is a need for further research on the effect of location on purchasing decisions.

The influence of stand location and booth design through positive emotion on purchasing decisions made at a wedding expo in East Java that has never been seen before discussed in previous research. This research is considered important because the results of this study will provide insight into the importance of choosing a stand location and choosing a decoration design in an exhibition. Vendors participating in an exhibition are currently very careful in choosing a 


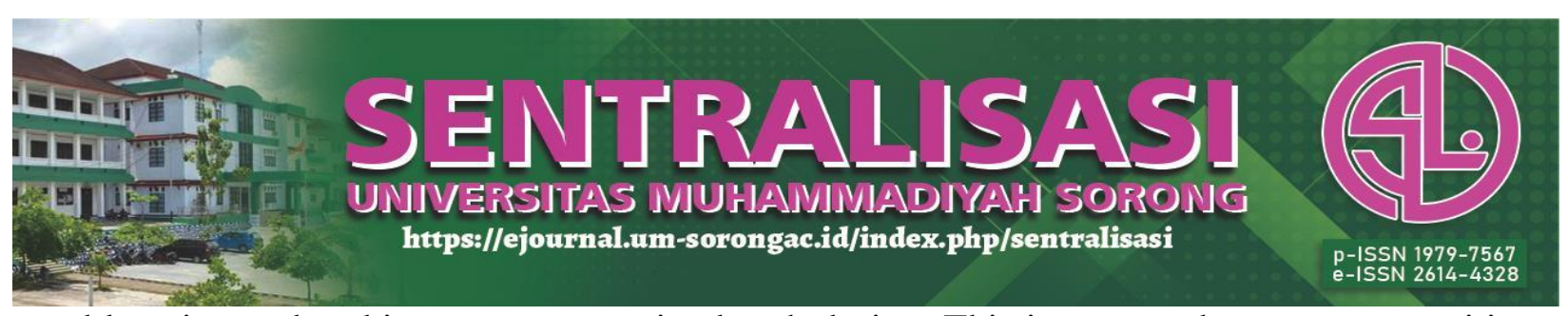

stand location and making a very attractive booth design. This is expected to generate positive emotions for consumers so that they can make purchasing decisions during the exhibition.

The purposes of this study were 1) The effect of stand location on positive emotion, 2) The effect of booth design on positive emotion, 3) The influence of positive emotion on purchasing decisions, 4) the influence of stand location on purchasing decisions, 5) the effect of booth design on purchasing decisions. , 6) The effect of stand location on purchasing decisions through positive emotion, 7) The effect of booth design on purchasing decisions through positive emotion.

\section{Research Method}

This study is a quantitative research using descriptive approach. The setting of this research is an exhibition held by Noble Entertainment which was held at MOG Malang, Icon Mall Gresik and CITO Surabaya. For the research population are consumers who make purchases during exhibition activities. For the research sample technique is used accidental sampling technique. The population in this study is an infinite population which determine the sample size using the following (Widiyanto, 2008):

$n=\frac{Z^{2}}{4(M o e)^{2}}$

$n=\frac{(1,96)^{2}}{4(0,1)^{2}}$

$\mathrm{n}=96,04 \sim 100$

Explanation:

$\mathrm{n}$ : sample size

$\mathrm{Z}:$ Score at a certain level of significance (degree of confidence is determined $95 \%$ ) then $\mathrm{Z}=$

1.96 Moe : Margin of error with maximum error rate is $10 \%$

Looking at the sample measurement formula, the determination of the sample size is known to be 97 people and rounded up to 100 respondents using accidental sampling technique. The data collection of this research are questionnaires, observations and documentation. As for the measurement scale in this study, the Likert scale is used. The analysis technique uses Path Analysis using the Smart PLS 3.0 application.

\section{Results and Discussion}

Validity and Reliability

Test

\section{Construct Reliability}

Laily Muzdalifah 


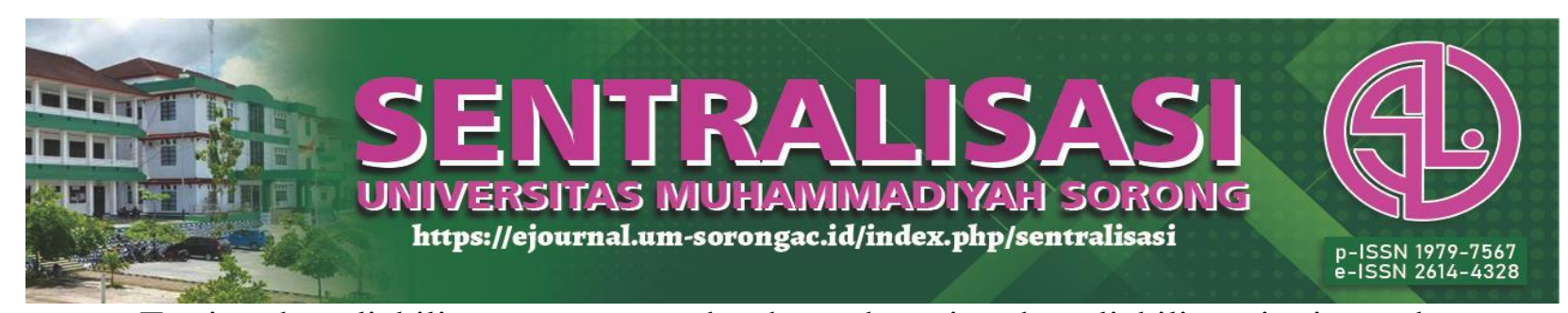

Testing the reliability construct can be shown by using the reliability criteria can be shown in table 1 below:

Table 1. Composite Reliabelty, Crombach Alpha dan Average Variance Extracted (AVE)

\begin{tabular}{|c|c|c|c|}
\hline & Cronbach's Alpha & $\begin{array}{l}\text { Composite } \\
\text { Reliability }\end{array}$ & $\begin{array}{l}\text { Average Variance } \\
\text { Extracted (AVE) }\end{array}$ \\
\hline design booth & 0.956 & 0.968 & 0.884 \\
\hline keputusan pembelian & 0.904 & 0.929 & 0.728 \\
\hline positive emotion & 0.909 & 0.943 & 0.846 \\
\hline stand location & 0.920 & 0.933 & 0.634 \\
\hline
\end{tabular}

Source: Data analysis SemPLS 3.0

The results of the analysis in table 1 . It is explained that the composite reliability value of the booth design, purchase decision, positive emotion, and stand location variables has a value $>0.70$ which means reliable. The Crombach Alpha value of the four variables has a value > 0.60 so it can be interpreted as reliable. AVE has a value $>0.50$ then the AVE value is interpreted as reliable.

\section{Outer Loading}

Construct validity testing can be explained using Outer Loading as follows:

Table 2. Outer Loading

\begin{tabular}{lrrrr}
\hline & $\begin{array}{c}\text { Original } \\
\text { Sample (O) }\end{array}$ & $\begin{array}{c}\text { Sample } \\
\text { Mean (M) }\end{array}$ & $\begin{array}{c}\text { Standard Deviation } \\
(\text { STDEV })\end{array}$ & $\begin{array}{c}\text { T Statistics } \\
(|\mathrm{O} / \mathrm{STDEV}|\end{array}$ \\
\hline DB1 <- design booth & 0.947 & 0.946 & 0.029 & 33.026 \\
\hline DB2 <- design booth & 0.925 & 0.924 & 0.033 & 27.952 \\
\hline DB3 <- design booth & 0.938 & 0.938 & 0.043 & 21.813 \\
\hline DB4 <- design booth & 0.950 & 0.947 & 0.086 & 21.897 \\
\hline KP1 <- keputusan pembelian & 0.741 & 0.727 & 0.094 & 7.570 \\
\hline KP2 <- keputusan pembelian & 0.703 & 0.689 & 0.023 & 40.990 \\
\hline KP3 <- keputusan pembelian & 0.923 & 0.922 & 0.017 & 54.383 \\
\hline KP4 <- keputusan pembelian & 0.934 & 0.935 & 0.016 & 58.127 \\
\hline KP5 <- keputusan pembelian & 0.933 & 0.935 & 0.025 & 36.877 \\
\hline PE1 <- positive emotion & 0.926 & 0.924 & 0.041 & 22.296 \\
\hline PE2 <- positive emotion & 0.903 & 0.899 & 0.027 & 34.505 \\
\hline PE3 <- positive emotion & 0.930 & 0.926 & 0.040 & 20.460 \\
\hline ST1 <- stand location & 0.827 & 0.824 & 0.051 & 15.334 \\
\hline ST2 <- stand location & 0.786 & 0.781 & 0.047 & 17.276 \\
\hline ST3 <- stand location & 0.809 & 0.804 & 0.056 & 13.728 \\
\hline ST4 <- stand location & 0.775 & 0.769 & 0.041 & 20.428 \\
\hline ST5 <- stand location & 0.837 & 0.831 & 0.035 & 22.905 \\
\hline ST6 <- stand location & 0.811 & 0.809 & 0.040 & 20.026 \\
\hline ST7 <- stand location & 0.797 & 0.794 & 0.048 & 15.120 \\
\hline ST8 <- stand location & 0.722 & 0.721 & & \\
\hline
\end{tabular}

Source: Data Ananlysis SemPLS 3.0 


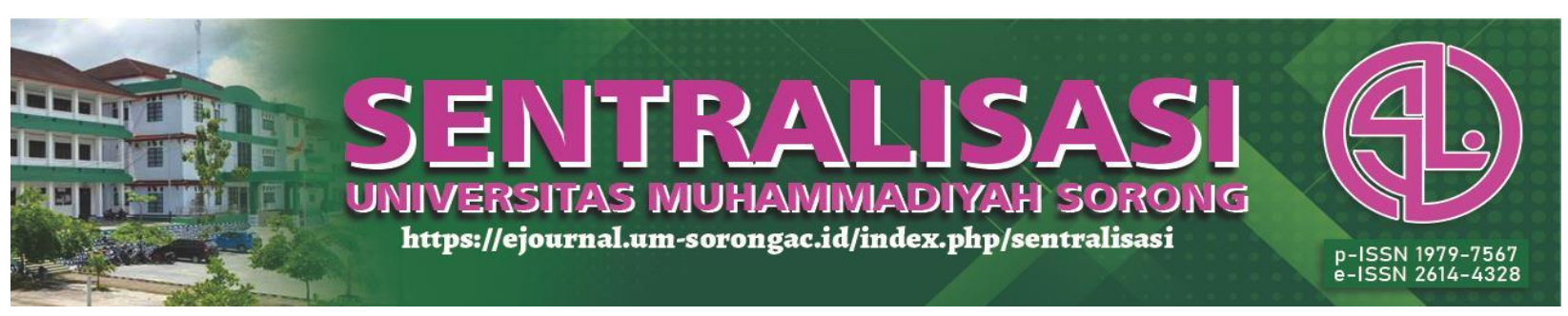

The results of the analysis in table 2. describe the Outer Loading value for each indicator of the stand location, booth design, purchase decision and positive emotion variable having an Outer Loading value $>0.50$. emotion, and stand location.

\section{Descriminant validity}

The discriminant validity test is assessed based on the cross loading measurement with the construct.

Tabel 3. Descriminant validity

\begin{tabular}{|c|c|c|c|c|}
\hline & design booth & $\begin{array}{l}\text { keputusan } \\
\text { pembelian }\end{array}$ & positive emotion & stand location \\
\hline DB1 & 0.947 & & & \\
\hline B2 & 0.925 & & & \\
\hline DB3 & 0.938 & & & \\
\hline DB4 & 0.950 & & & \\
\hline KP1 & & 0.741 & & \\
\hline KP2 & & 0.703 & & \\
\hline KP3 & & 0.923 & & \\
\hline KP4 & & 0.934 & & \\
\hline KP5 & & 0.933 & & \\
\hline PE1 & & & 0.926 & \\
\hline PE2 & & & 0.903 & \\
\hline PE3 & & & 0.930 & \\
\hline ST1 & & & & 0.827 \\
\hline ST2 & & & & 0.786 \\
\hline ST3 & & & & 0.809 \\
\hline ST4 & & & & 0.775 \\
\hline ST5 & & & & 0.837 \\
\hline ST6 & & & & 0.811 \\
\hline ST7 & & & & 0.797 \\
\hline ST8 & & & & 0.722 \\
\hline
\end{tabular}

Source: Data Analysis SemPLS 3.0

The results of table 3 . The difference in indicator values on the latent variable seen from the cross loading value has a value $>0.7$ for each booth design variable, purchase decision, positive emotion, and stand location.

\section{Hypothesis testing}

\section{Output Model}

Based on the conceptual framework made in this study, it shows the output model in Figure 1 below: 


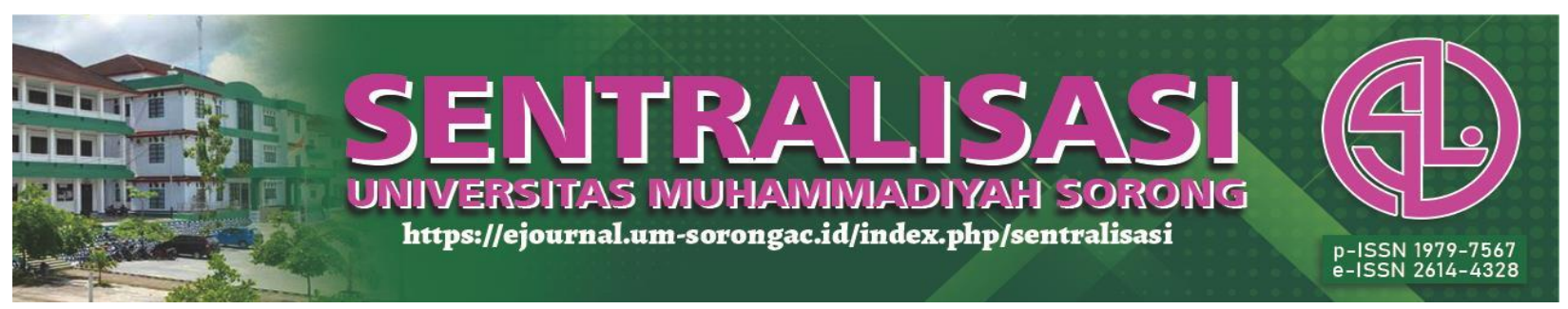

Source: Data Analysis SemPLS 3.0

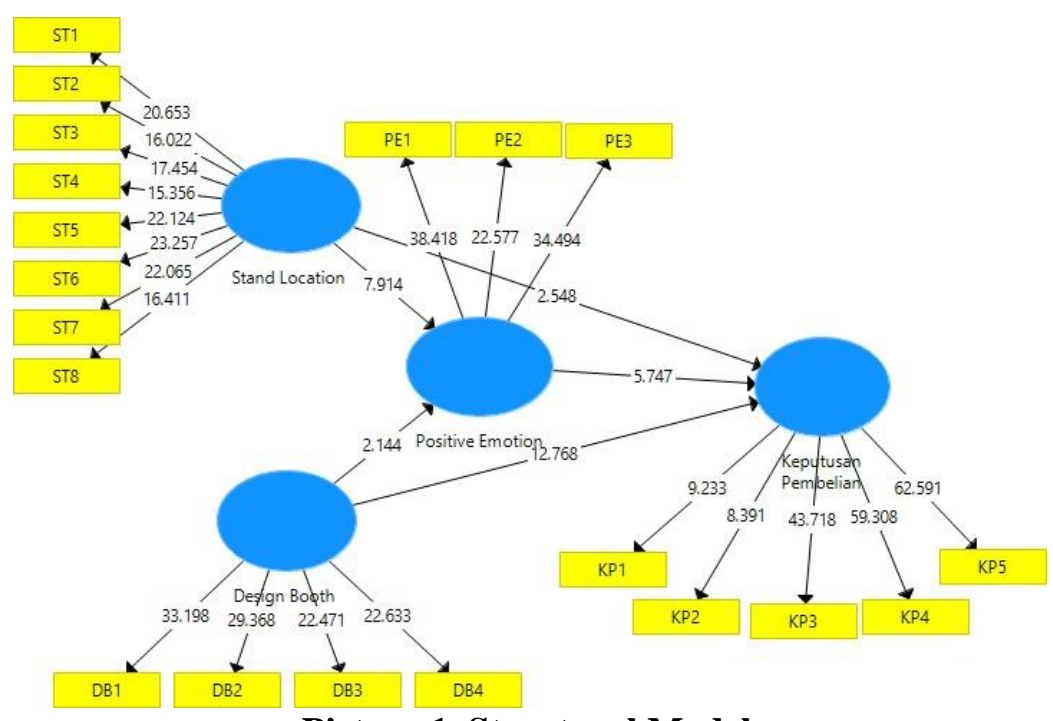

Picture 1. Structural Model

\section{Goodness Of Fit Model}

The R-square value in the study is used to determine the effect of the magnitude of the influence of the dependent variable which can be shown in table 4 as follows:

Table 4. $R$-square

\begin{tabular}{lr}
\hline & R Square \\
\hline Purchasing decision & 0.940 \\
positive emotion & 0.661 \\
\hline
\end{tabular}

Source: Data Analysis SemPLS 3.0

The results of table 4. explain that the R-square value of the purchasing decision variable is 0.940 , where the stand location and booth design variables can explain $94 \%$ purchasing decisions. while the remaining $100 \%-94 \%=6 \%$ can explain other variables to influence purchasing decisions. The R-square value of the positive emotion variable is 0.661 , which means that the stand location and booth design can explain the positive emotion of $66.1 \%$. while the remaining $100 \%-66.1 \%=33.9 \%$ can explain other variables to influence positive emotion.

\section{Hypothesis test}

The results of hypothesis testing contained in table 5 path coefficients are shown in The estimated output for testing the structural model is as follows:

Table 5. Output Result For Inner Weight

\begin{tabular}{lccccc}
\hline & $\begin{array}{l}\text { Original } \\
\text { Sample (O) }\end{array}$ & $\begin{array}{l}\text { Sample } \\
\text { Mean } \\
(\mathbf{M})\end{array}$ & $\begin{array}{l}\text { Standard } \\
\text { Deviation } \\
(\text { STDEV) }\end{array}$ & $\begin{array}{l}\text { T Statistics } \\
(\mid \mathbf{O} / \text { STDEV })\end{array}$ & P Values \\
\hline $\begin{array}{l}\text { design booth }-> \\
\begin{array}{l}\text { keputusan } \\
\text { pembelian }\end{array}\end{array}$ & 0.651 & 0.653 & 0.052 & 12.460 & 0.000 \\
& & & & & \\
\end{tabular}




\begin{tabular}{|c|c|c|c|c|c|}
\hline \multirow{2}{*}{\multicolumn{6}{|c|}{ 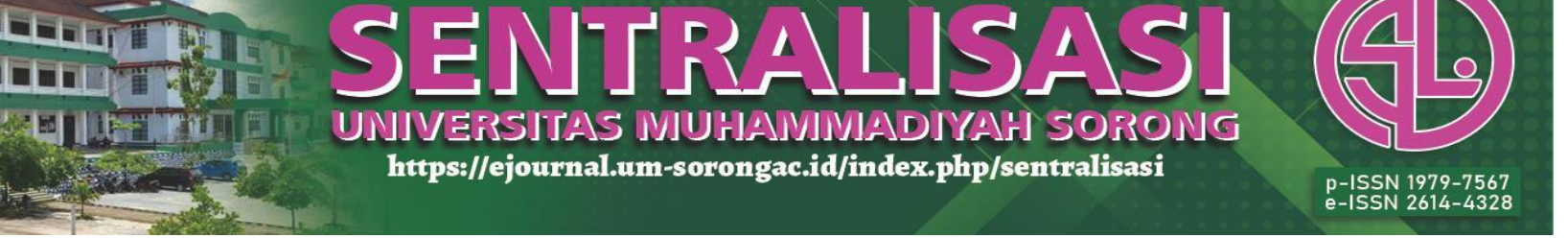 }} \\
\hline & & & & & \\
\hline $\begin{array}{l}\text { design booth }->\text { positive } \\
\text { emotion }\end{array}$ & 0.256 & 0.247 & 0.119 & 2.144 & 0.033 \\
\hline $\begin{array}{l}\text { positive emotion -> } \\
\text { keputusan pembelian }\end{array}$ & 0.275 & 0.272 & 0.050 & 5.485 & 0.000 \\
\hline $\begin{array}{l}\text { stand location -> } \\
\text { keputusan pembelian }\end{array}$ & 0.133 & 0.135 & 0.052 & 2.542 & 0.011 \\
\hline $\begin{array}{l}\text { stand location }->\text { positive } \\
\text { emotion }\end{array}$ & 0.614 & 0.618 & 0.075 & 8.221 & 0.000 \\
\hline
\end{tabular}

Source: Data Analysis SemPLS 3.0

The results of the direct effects hypothesis test analysis in table 5 can be explained as follows: 1) Booth design has a direct effect on purchasing decisions with a T-statistic value of $12,460>1.96$ with a P-value of 0.000. 2) Booth design has a direct effect on positive emotion with a T-statistic value $2.144>1.96$ with a P-Value value of 0.033. 3) Positive emotion directly affects purchasing decisions with a T-statistical value of $5485>1.96$ with a P-Value value of 0.000. 4) Stand location has a direct effect on purchasing decisions with a T-statistic value of $2.542>1.96$ with a P-Value value of 0.011. 5) Stand location has a direct effect on positive emotion with a Tstatistic value $8,221>1.96$ with a P-Value of 0.000 .

Table 6. Output Result For Inner Weight

\begin{tabular}{lccccc}
\hline & $\begin{array}{l}\text { Original } \\
\text { Sample (O) }\end{array}$ & $\begin{array}{l}\text { Sample } \\
\text { Mean (M) }\end{array}$ & $\begin{array}{l}\text { Standard } \\
\text { Deviation } \\
\text { (STDEV) }\end{array}$ & $\begin{array}{l}\text { T Statistics } \\
(\mid \mathbf{O S T D E V})\end{array}$ & P Values \\
\hline $\begin{array}{l}\text { design booth -> } \\
\text { positive emotion -> } \\
\text { keputusan } \\
\text { pembelian } \\
\text { stand location -> } \\
\text { positive emotion -> }\end{array}$ & 0.070 & 0.169 & 0.037 & 1.991 & $\mathbf{0 . 0 4 9}$ \\
$\begin{array}{l}\text { keputusan } \\
\text { pembelian }\end{array}$ & 0.169 & 0.167 & 0.035 & 4.836 & $\mathbf{0 . 0 0 0}$ \\
\hline
\end{tabular}

Source:Data Analysis SemPLS 3.0

The results of the indirect effects hypothesis testing analysis can be explained in table 6 below: 1) Booth design has an indirect effect on purchasing decisions through positive emotion with a T-statistic value of $1.991>1.96$ with a P-value of 0.049. 2) Stand location indirectly influences purchasing decisions through positive emotion using a T-statistic value of $4.836>1.96$ with a P-Value of 0.000 .

\section{Discussion}

\section{Stand location for positive emotion}

Based on the results of the data analysis, it can be explained in the discussion that stand location has a direct effect on positive emotion. This means that the event organizer will provide 


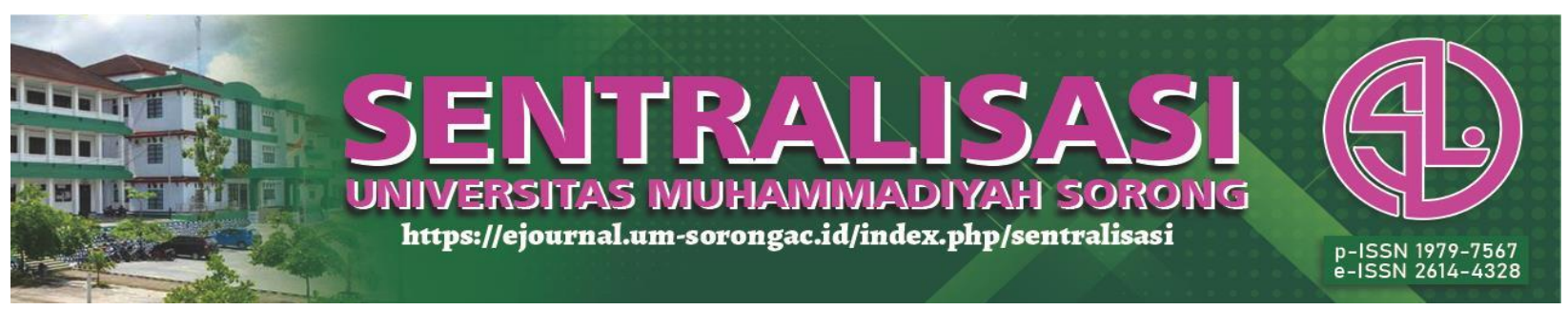

convenience in providing a location for consumers to visit because with a strategic stand location, easily accessible by consumers, it can generate positive thoughts for consumers to be able to visit directly because consumers will be younger and will not be confused about what to do. looking for a stand location.

\section{Design booth for positive emotions}

Based on the results of the analysis above, it can be explained in the discussion that booth design has a direct effect on positive emotion. This is in line with research conducted by (Bloch et al. 2017) that "Firms planning to exhibit at a trade show need to incorporate aesthetic considerations into their strategy to attract the relevant audience to their booth". Companies planning to exhibit at trade shows need to incorporate aesthetic considerations into their strategy to attract relevant audiences to their booths.

An attractive booth design will attract the attention of consumers to enter the exhibition stand. The booth design carried out by wedding vendors, of course, must have a theme and be in accordance with the products offered. Examples of exhibition booth designs are as follows:

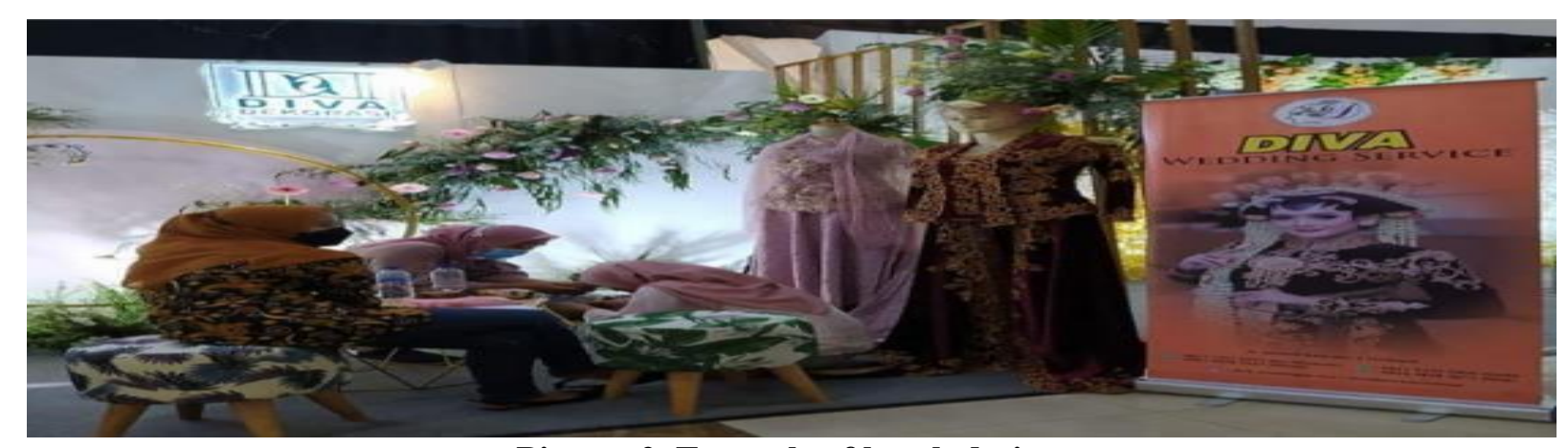

Picture 2. Example of booth design

For example, a wedding exhibition vendor participated in by one of the wedding decoration entrepreneurs. The stands displayed must match the products offered so that consumers who visit the stand will have an idea of the wedding decorations that will be used at the time of the wedding. The more attractive the booth design will make consumers have positive emotions towards the booth design seen at the exhibition.

\section{Positive emotion towards purchasing decisions}

Based on the results of the analysis above, it can be explained in the discussion that positive emotion has a direct effect on purchasing decisions. Companies that are able to provide services that exceed customer expectations will create positive feelings (Barnes; 2013); (Pragita, Fauzi, and Kumadji 2013). In line with research conducted by Pragita, et al (2010) showed that positive emotions affect purchasing decisions. The increase in positive emotions can increase the likelihood 


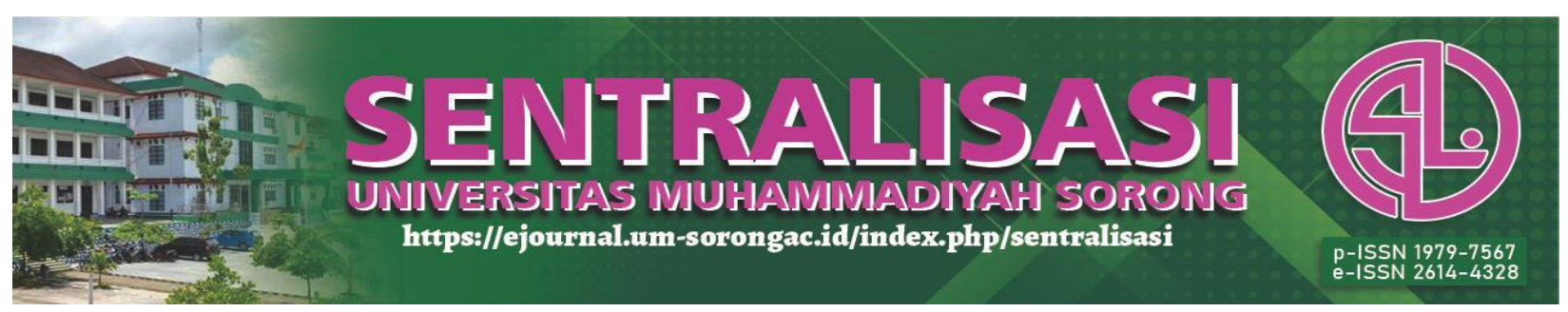

of a greater purchase decision.

\section{Stand location on purchasing decisions}

Based on the results of the analysis above, it can be explained in the discussion that the stand location has a direct effect on buying decisions. These results indicate that the better the location, the higher the value of consumer buying decisions. The strategic stand location at an exhibition is expected to make it easier for visitors to find the location of the stand. In line with research by Baiti, Purba, and Yandi (2013), it shows that location has an effect on purchasing decisions. The ease of getting the location of the stand will encourage consumers to come to the location of the exhibition stand. The layout of the stands at the tough wedding exhibition can be seen in the display below:

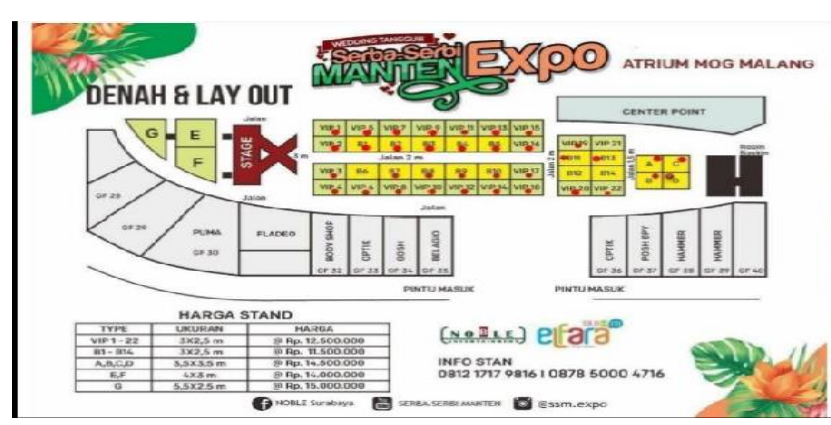

Picture 3.

Stand location MOG Malang

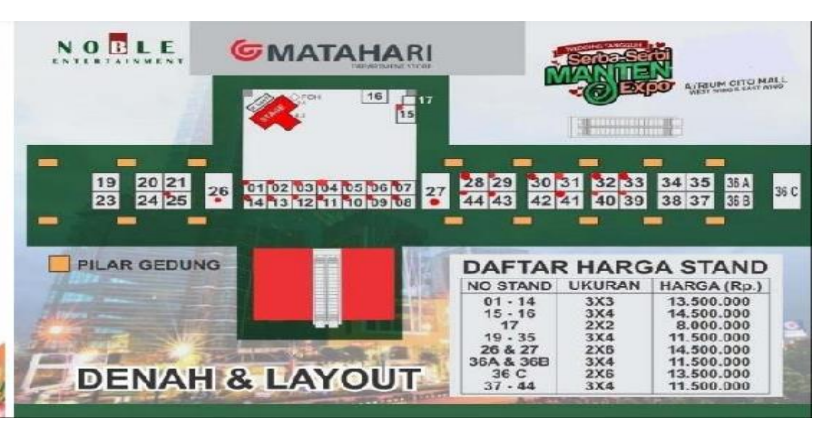

Picture 4.

Stand location CITO Surabaya

Source : Noble Entertainment data

The picture shows that each stand has a serial number and the price of the exhibition stand also varies greatly depending on the location of the exhibition stand. Wedding entrepreneurs, of course, have to be good at having a strategic stand location to make it easier for potential customers to visit the exhibition stand. This must be considered properly so that the costs that are already large enough to rent the stand are not wasted. The best stand location is the stand location that is most easily seen and reached by the visitors.

\section{Booth design on purchasing decisions}

Based on the results of the analysis above, it can be explained in the discussion that the booth design has a significant effect on purchasing decisions. An attractive booth design can improve purchasing decisions. The main thing that needs to be considered when implementing a booth design in an exhibition is to be able to communicate the goals of the exhibitor (Iskandar, Novianto, \& Susan 2017). Exhibition is one of the promotion media development for companies. According to the United States Small Business Administration (SBA) (Ririsaci 2020) one of the benefits of an exhibition is to generate transactions during the exhibition. 


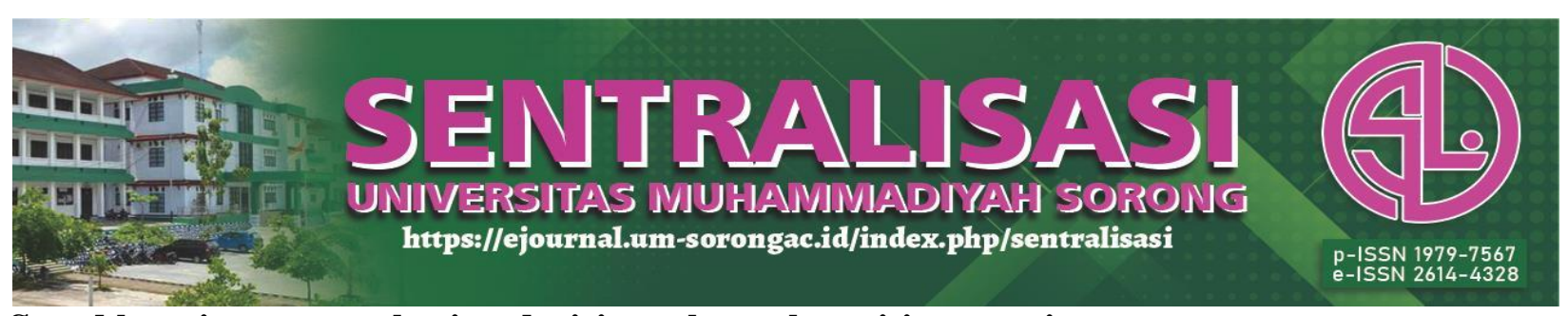

\section{Stand location on purchasing decisions through positive emotion}

Based on the results of the analysis above, it can be explained in the discussion that booth design has a significant effect on purchasing decisions through positive emotion. The convenience of consumers in finding and visiting the location of the stand will form a positive emotion which will affect the purchase decision. The most important factor in the success of an event is called location (Fatiara, Silitonga, \& Eviana, 2017). In choosing a location for the show, you should pay attention that the exhibition location has a trande show, evidence of a high traffic area and knows who is showing the location of the surrounding exhibition stands (Abifadli 2015).

\section{Design booth on purchasing decisions through positive emotion}

Based on the results of the analysis above, it can be explained in the discussion that the stand location has a significant effect on purchasing decisions through positive emotion. An attractive booth design will foster a positive emotion for exhibition visitors which will have an impact on purchasing decisions. According to Barnes (2003) every customer has the hope of getting satisfaction, so with the satisfaction provided by the company, positive emotions will emerge. So to form a positive emotion through a booth design, wedding entrepreneurs must create a booth design that is not only attractive, but the booth design is representative of the products offered.

\section{Conclusion}

The conclusion of this study shows that the Stand location and Design Booth have an influence either directly or through the positive emotion variable. This research was conducted so that wedding entrepreneurs who participated in wedding exhibitions pay attention to strategies in choosing a stand location and design a booth that is quite attractive according to the theme. An attractive and appropriate stand location and booth design can influence consumer purchasing decisions during the exhibition. A strategic stand location and attractive booth design will build positive emotions for consumers so as to trigger consumers to make purchasing decisions. At the stand location in order to attract the attention of consumers, vendors should choose the most accessible place for consumers and easily seen by consumers. Making a nameplate that is arranged in such a way that consumers can read the vendor's name writing remotely. In addition, vendors can ensure that the EO of the exhibition can help recommend and show the location of the stand to consumers, for example the existence of an event guide at the entrance and a map of the exhibition location.

The booth design that is used must certainly attract consumers to visit, because after all, when the booth design looks very attractive, it will generate positive emotions for consumers so 


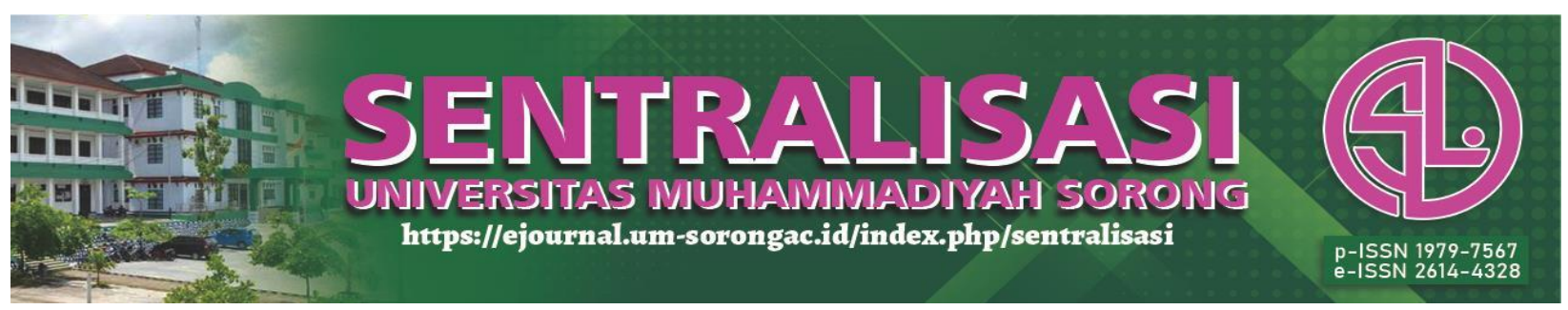

they are interested in visiting the stand location. The booth design can be done by adding ornaments with striking colors, unique accessories, displaying the vendor's superior products, adequate lighting and so on. The next researcher can explain the variables measuring purchasing decisions for wedding exhibitions that are not examined in the research. There are many things that trigger consumers' buying decisions at the time of the exhibition besides the variables studied in this study, for example, prices, promotions, endorsements, single shows, etc.

\section{References}

\section{Books}

Abdillah, Willy dan Jogiyanto. 2015. Partial Least Square (PLS). Yogyakarta : Andi.

Kopec, D. (2006), Environmental Psychology for Design. London: Bloomsbury Academic.

Kotler \& Keller. 2009.Manajemen Pemasaran Edisi 13 Jilid 1. Jakarta : Erlangga.

Tjiptono, Fandy. 2019. Strategi Pemasaran Edisi-4. Yogyakarta : Andi.

Widiyanto, Ibnu. 2008. Pointers: Metodologi Penelitian. BP Undip, Semarang.

Mehrabian, A., and Russell, J. A. (1974). An Approach to Environmental Psychology. in Fisher, Feffrey D., Paul A. Bell, and Andrew Baum (1984). In Environmental Psycholog (2nd ed.). New York: Holt, Rinehart and Winston

\section{Articles}

Abifadli. 2015. "Cara Memilih Tempat Meletakan Booth Pameran Anda Di Setiap Acara _Kontraktor Booth Pameran.” Retrieved (https://boothpamerankontraktor.wordpress.com/2015/03/13/cara-memilih-tempatmeletakan-booth-pameran-anda-di-setiap-acara/).

Drapeau, N. (2012), "New insights on trends in marketing spend on business-to-business exhibitions", available at: http://www.ceir.org.

Ririsaci. 2020. “Inilah 11 Manfaat Mengikuti Pameran Bagi Bisnis - Ririsaci Studio.” Retrieved (https://ririsaci.com/inilah-11-manfaat-mengikuti-pameran-bagi-bisnis-ririsaci-studio/).

\section{Journals}

Baiti, Mita, Antony Stefanus Purba, and Ferdi Silva Yandi. 2013. "Pengaruh Lokasi, Harga Dan Fasilitas Hotel Terhadap Keputusan Menginap Pelanggan.” Jurnal Ilmiah Akuntansi Dan Pariwisata 1:47-58.

Bitner, M.J. (1992), "Servicescapes: The impact of physical surroundings on customers and employees", Journal of Marketing, 56(April), 57-71.

Bloch, Peter H., Srinath Gopalakrishna, Andrew T. Crecelius, and Marina Scatolin Murarolli. 2017. "Exploring Booth Design as a Determinant of Trade Show Success." Journal of Business-to-Business Marketing 24(4):237-56. doi: 10.1080/1051712X.2018.1381399. 


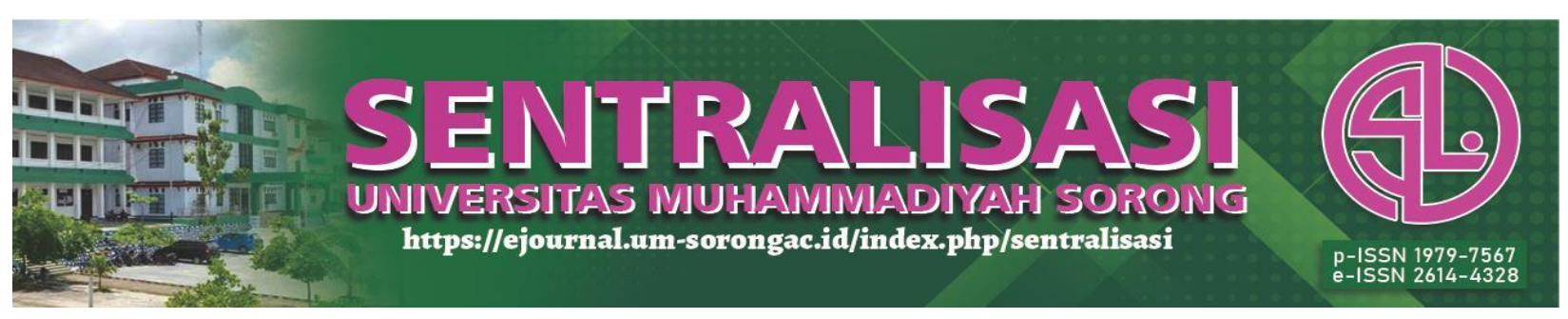

Fatiara, Syiar, Silitonga, and Nova Eviana. 2017. "Pengaruh Lokasi, Kualitas Produk Dan Event Terhadap Keputusan Berwisata Ke Museum Bank Indonesia Jakarta.” Eduturisma, Edisi $\mathrm{Ke}-2$ 1(2):60-74.

Fawzeya, Nuril. 2017. "Pengaruh Harga, Kualitas Pelayanan, Dan Lokasi Terhadap Keputusan Pembelian." 1-14.

Gunawan Kwan, O. (2016). Pengaruh Sales Promotion Dan Store Atmosphere Terhadap Impulse Buying Dengan Positive Emotion Sebagai Variabel Intervening Pada Planet Sports Tunjungan Plaza Surabaya. Jurnal Manajemen Pemasaran, 10(1), 27-34. https://doi.org/10.9744/pemasaran.10.1.27-34

Hermanto, Elleinda Yulia. 2016. "Pengaruh Fashion Involvement Terhadap Impulse Buying Behaviour Masyarakat Surabaya Dengan Hedonic Shopping Motivation Dan Positive Emotion Sebagai Variabel Intervening Pada Merek Zara." Jurnal Manajemen Pemasaran 10(1):11-19. doi: 10.9744/pemasaran.10.1.11-19.

Iskandar, Ferdinant Yansen, Tri Novianto, and M. .. Susan. 2017. "Perancangan Desain Booth Pameran 'Citi-9, Indonesia Pavilun, Chevrolet' Di Gresik Dan Jakarta." Arsitektur Interior 2.

Kaplan, S. (1988), "Where cognition and affect meet: A theoretical analysis of preference", in Nasar, J. (Ed.), Environmental Aesthetics, "Cambridge: Cambridge University Press, 5663.

Lebrecque, L. I., Patrick, V.M. and Milne, G.R. (2013), “The Marketers' Prismatic Palette: A Review of Color Research and Future Directions," Psychology and Marketing, 30 (2), 179- 86.

Pragita, Atika Ayu, Achmad DH Fauzi, and Srikandi Kumadji. 2013. "Pengaruh Store Atmosphere (Suasana Toko) Terhadap Emosi Dan Dampaknya Kepada Keputusan Pembelian." Jurnal Profit 7:1-11.

Syiar Fatiara, Dr. P. Silitonga, MBA, Nova Eviana, S.S., M. P. (2017). Pengaruh Lokasi, Kualitas Produk Dan Event Terhadap Keputusan Berwisata Ke Museum Bank Indonesia Jakarta. Eduturisma, Edisi Ke-2, 1(2), 60-74.

Van Oel, C.J., and Van den Berkhof, D. (2013), “Consumer preferences in the design of airport passenger areas", Journal of Environmental Psychology, 36, 280-290. 